OPEN ACCESS

Check for updates

\title{
Association between home insulation and hospital admission rates: retrospective cohort study using linked data from a national intervention programme
}

\author{
Caroline Fyfe, ${ }^{1}$ Lucy Telfar-Barnard, ${ }^{1}$ Philippa Howden-Chapman, ${ }^{1}$ Jeroen Douwes ${ }^{2}$
}

${ }^{1}$ He Kianga Oranga, Department of Public Health, University of

Otago Wellington, PO Box 7343 , Wellington South 6242, New.

Zealand

${ }^{2}$ Centre for Public Health Research, Massey University Wellington, New Zealand

Correspondence to: C Fyfe fyfca725@student.otago.ac.nz (ORCID 0000-0002-6087-8339) Additional material is published online only. To view please visit the journal online.

Cite this as: $B M J$ 2020;371:m4571 http://dx.doi.org/10.1136/bmj.m4571

Accepted: 21 October 2020

\section{ABSTRACT}

OBJECTIVES

To investigate whether retrofitting insulation into homes can reduce cold associated hospital admission rates among residents and to identify whether the effect varies between different groups within the population and by type of insulation.

DESIGN

A quasi-experimental retrospective cohort study using linked datasets to evaluate a national intervention programme.

\section{PARTICIPANTS}

994317 residents of 204405 houses who received an insulation subsidy through the Energy Efficiency and Conservation Authority Warm-up New Zealand: Heat Smart retrofit programme between July 2009 and June 2014.

\section{MAIN OUTCOME MEASURE}

A difference-in-difference approach was used to compare the change in hospital admissions of the study population post-insulation with the change in hospital admissions of the control population that did not receive the intervention over the same two timeframes. Relative rate ratios were used to compare the two groups.

RESULTS

234873 hospital admissions occurred during the study period. Hospital admission rates after the intervention increased in the intervention and control groups for all population categories and conditions with the exception of acute hospital admissions among Pacific Peoples (rate ratio 0.94, 95\% confidence interval 0.90 to 0.98$)$, asthma $(0.92,0.86$ to 0.99$)$, cardiovascular disease $(0.90,0.88$ to 0.93$)$, and ischaemic heart disease for adults older than 65

\section{WHAT IS ALREADY KNOWN ON THIS TOPIC}

Excess winter mortality and morbidity are often greater in countries with relatively mild climates than in countries with colder climates

This paradox has been linked to poorer thermal efficiency of housing in temperate countries leading to colder indoor temperatures and creating an environment more susceptible to damp and mould

Several intervention studies have shown that improving thermal efficiency can lead to (most often self-reported) improvement in symptoms of cold associated disease

\section{WHAT THIS STUDY ADDS}

Retrofitting home insulation was associated with a reduction in the frequency of hospital admissions

The magnitude of the reduction was more pronounced for respiratory disease years $(0.79,0.74$ to 0.84$)$. Post-intervention increases were, however, significantly lower (11\%) in the intervention group compared with the control group (relative rate ratio $0.89,95 \%$ confidence interval 0.88 to 0.90$)$, representing 9.26 (95\% confidence interval 9.05 to 9.47 ) fewer hospital admissions per 1000 in the intervention population. Effects were more pronounced for respiratory disease $(0.85,0.81$ to $0.90)$, asthma in all age groups $(0.80,0.70$ to 0.90$)$, and ischaemic heart disease in those older than 65 years $(0.75,0.66$ to 0.83$)$.

\section{CONCLUSION}

This study showed that a national home insulation intervention was associated with reduced hospital admissions, supporting previous research, which found an improvement in self-reported health.

\section{Introduction}

Excess winter mortality and morbidity are often greatest in countries with relatively mild climates, including New Zealand, probably because of poorer thermal housing standards compared with well insulated houses in colder climates. ${ }^{1-3}$ Cold houses are also associated with indoor dampness and mould, both consistently linked to an increased risk of respiratory symptoms, with strong evidence for asthma exacerbations and respiratory infections, and limited evidence for asthma development. ${ }^{4-6}$ Several intervention studies involving improved thermal insulation or heat supply, or both have shown a reduction in respiratory symptoms and improved self-reported health, but these studies were either qualitative ${ }^{78}$ or did not have sufficient statistical power to obtain significant results for hospital admissions. ${ }^{9}$ Taken together, the evidence suggests a role for indoor cold in increased mortality and morbidity, with improved insulation having the potential to mitigate these effects. ${ }^{10-13}$ As relatively few intervention studies or natural experiments of sufficient size have been conducted, however, a gap remains in quantitative evidence for the role of insulation in mitigating the health impacts of cold housing.

Most homes in New Zealand are cold by international standards and do not meet the World Health Organization's recommended minimum indoor temperature of $18^{\circ} \mathrm{C} .^{10-121415}$ Most of the housing stock was built between 1950 and 2000 and consists of timber framed, single storey, detached houses with either a brick or a weatherboard skin. ${ }^{16} 17$ Before a 1977 amendment to the building code (NZS 421P) there was no requirement to insulate homes. Since then, new homes are required to be insulated, but 
retrofitting insulation into existing homes has been at the discretion of the homeowner. In 2005 an estimated $60 \%$ of houses built before 1979 lacked any form of ceiling insulation, and $68 \%$ were without underfloor insulation. In addition, $37 \%$ of houses built in the 1980 s and $26 \%$ built in the 1990 s had levels of ceiling insulation that were insufficient to meet even the 1977 standard. ${ }^{16}$

In 2009, the New Zealand Energy Efficiency and Conservation Authority established an insulation subsidy programme for existing homes, Warm-up New Zealand: Heat Smart (WUNZ). This programme ran from June 2009 to July 2014 and represented a government investment of NZ\$347m (£181m; \$241m; €203m). As insulation levels had been revised several times since 1977 , houses that received a WUNZ subsidy needed to retrofit insulation that conformed to the 2007 insulation standard (NZBC clause H1/AS1). ${ }^{13}$ This standard sets out the requirements for the thermal resistance ( $R$ value) of insulation according to the climate zone in which the house is situated (see fig 1). All owners of houses built before 2000 were eligible; however, the level of the subsidy was based on two income categories-those on a low income received a $60 \%$ subsidy, whereas those on a general income received a 33\% subsidy, capped at NZ\$1300 in each case. At the time the WUNZ programme operated, the average cost of insulating a home was estimated to be around NZ\$3000. Some local authorities offered interest-free loans (repaid through rates) to cover the balance of the cost. ${ }^{18} \mathrm{~A}$ heater subsidy for houses with no fixed form of heating, or to replace an open fire or inefficient log burner, was initially included as part of the overall WUNZ budget. This subsidy was set at NZ\$500 for households on a general income and NZ\$1200 for those on a low income. ${ }^{18}$ It was phased out, ending in December 2012, after an economic evaluation of the programme concluded that insulating houses provided greater benefit than subsidising heaters. ${ }^{19}$

To assess whether retrofitting insulation was associated with reduced hospital admissions, we linked a dataset of more than 200000 houses insulated over the five years of the WUNZ subsidy programme to health data.

\section{Methods}

The study involved a retrospective cohort of all residents in New Zealand whose houses were insulated between 1 July 2009 and 31 December 2011 through the WUNZ subsidy programme. Residents of these houses were identified by address from primary health organisation records. These records include everybody registered with a general practitioner, and they are updated every quarter. We collected data for residents of WUNZ houses for three years before and three years after the insulation intervention. A difference-indifference approach was used to compare the before and after intervention change in hospital admissions of the study population with that of a control population over the same period. To ensure that the control group was similar to the intervention group, we included all residents whose houses were insulated through the WUNZ subsidy programme, but at a later date, between 1 January 2012 and 30 June 2014.

The intervention included ceiling insulation, underfloor insulation, and a top-up of existing ceiling insulation when it fell short of the 2007 standard. The type and amount of insulation installed depended on what already existed in the house and access to spaces requiring insulation. The programme did not extend to provision of double glazing or cavity wall insulation; both are rare in houses built before 2007. In a limited number of houses $(11.6 \%)$ a clean heating device was also installed. Most of these $(78.0 \%)$ were heat pumps, with a further $19.7 \%$ comprising energy efficient log burners. The remainder were made up of wood pellet burners (1.4\%) and flued gas heaters (1.0\%).

\section{Data linkage}

We used a WUNZ dataset as the basis for this study. The dataset contained records of all houses that received an insulation subsidy between July 2009 and June 2014, including address, date of the insulation retrofit, type and amount of insulation provided, and clean heating device installed, when applicable. We geocoded addresses using ArcGIS10.3 (a spatial analysis software package that can convert address information to a coordinate point on a map) to match with a Land Information New Zealand registered address. We then geocoded primary health organisation records for June 2006 to July 2014, matching them to the same Land Information New Zealand registered address format; and joined them to the WUNZ dataset using the address string (fig 2).

We assigned intervention and control groups and baseline and follow-up timeframes from the joined records. We collected baseline data for everyone who lived in the house for the three years before the installation of insulation, with the comparison baseline for the control group being between three and six years before insulation was installed. Follow-up included everyone who lived in the house during the three years after the insulation had been installed or until July 2014, if that was sooner. The comparison follow-up for the control group was the three years before insulation was installed (fig 3).

Person years contributed were calculated by the number of quarter years an individual lived in a WUNZ house (person-house pair). If a person moved from one WUNZ house to another, a new person-house pair was created. A nested cohort of those with six years continual occupancy (three years before insulation and three years after insulation, or six years before insulation in the control group) was also identified.

We obtained personal and health information from the New Zealand Ministry of Health for residents we identified as having lived in a WUNZ house during the study period. These were matched to each person-house linked record using the resident's national health index number. This number is assigned to each person who receives healthcare in New Zealand. Geographical area and area level deprivation, based on the New Zealand index of deprivation $2013,{ }^{20}$ were linked to the joined 


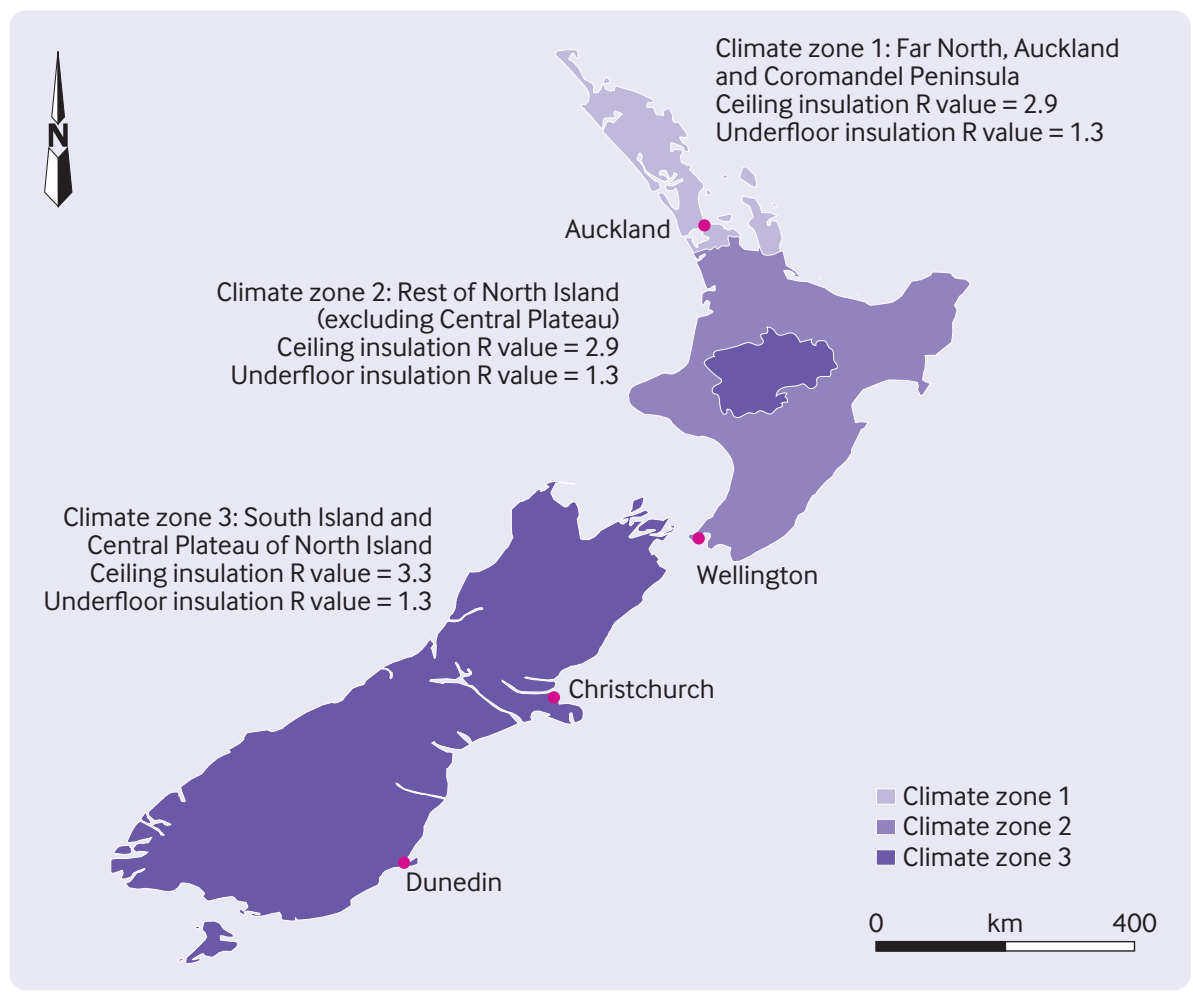

Fig 1 | Map of New Zealand climate zones. $R$ value is the thermal resistance of insulation set by the 2007 insulation standard

datasets using the meshblock in which the house was situated. A meshblock is the smallest geographical unit for which statistical data are available.

\section{Exclusions}

We excluded people aged 0 years or less or 90 years or more at baseline and when deprivation 10 th or sex were unknown or unassigned, as the data quality for these records was deemed inadequate. ${ }^{21}$ Records were also excluded when there was a gap in continuous residence of more than six months, owing to uncertainty about whether the address was a permanent residence (fig 2). Participants who died during the study were also excluded.

\section{Data analysis}

Total person years and hospital admissions contributing to the study were calculated. We also analysed subgroups of the population stratified by age, sex, ethnicity, area level deprivation (10ths aggregated into fifths for the analysis), climate zone, and type of insulation installed. All data analyses were conducted using SAS 9.4.

Poisson regression analysis was used to calculate baseline and follow-up hospital admission rates (number of hospital admissions divided by number of person years), determine rate ratios (hospital admission rate at follow-up divided by hospital admission rate at baseline) for the intervention and control groups, and to calculate relative rate ratios (intervention rate ratio divided by control rate ratio). Furthermore, we undertook Poisson regression analysis for the population subgroups. The use of person years rather than individuals as a denominator; variations in sex, ethnicity, and age within households; and changes in household composition over the six years covered by the study meant it was not possible to adjust for clustering in analyses involving the total population. To determine the impact on results of clustering by household we used a separate analysis undertaken on the six year continual occupancy nested cohort.

Absolute difference in the number of hospital admissions per 1000 population was measured by subtracting the change in adjusted hospital admission rates between baseline and follow-up in the intervention group from the change in adjusted hospital admission rates between baseline and followup in the control group.

Analysis of hospital admissions was undertaken based on a list of conditions identified by a previous study as housing related potentially avoidable hospital admissions. ${ }^{22}$ Because WUNZ did not include interventions to address household crowding that were provided in that study, we further refined this list to include only conditions associated with low ambient temperature, based on an evaluation of literature from more recent housing studies. ${ }^{132324}$ The final list of cold associated hospital admissions selected for analysis was: acute hospital admissions (non-elective admissions: excluding maternity and injury related), respiratory disease (international classification of diseases, 10th revision (ICD-10) codes J00-J99), 


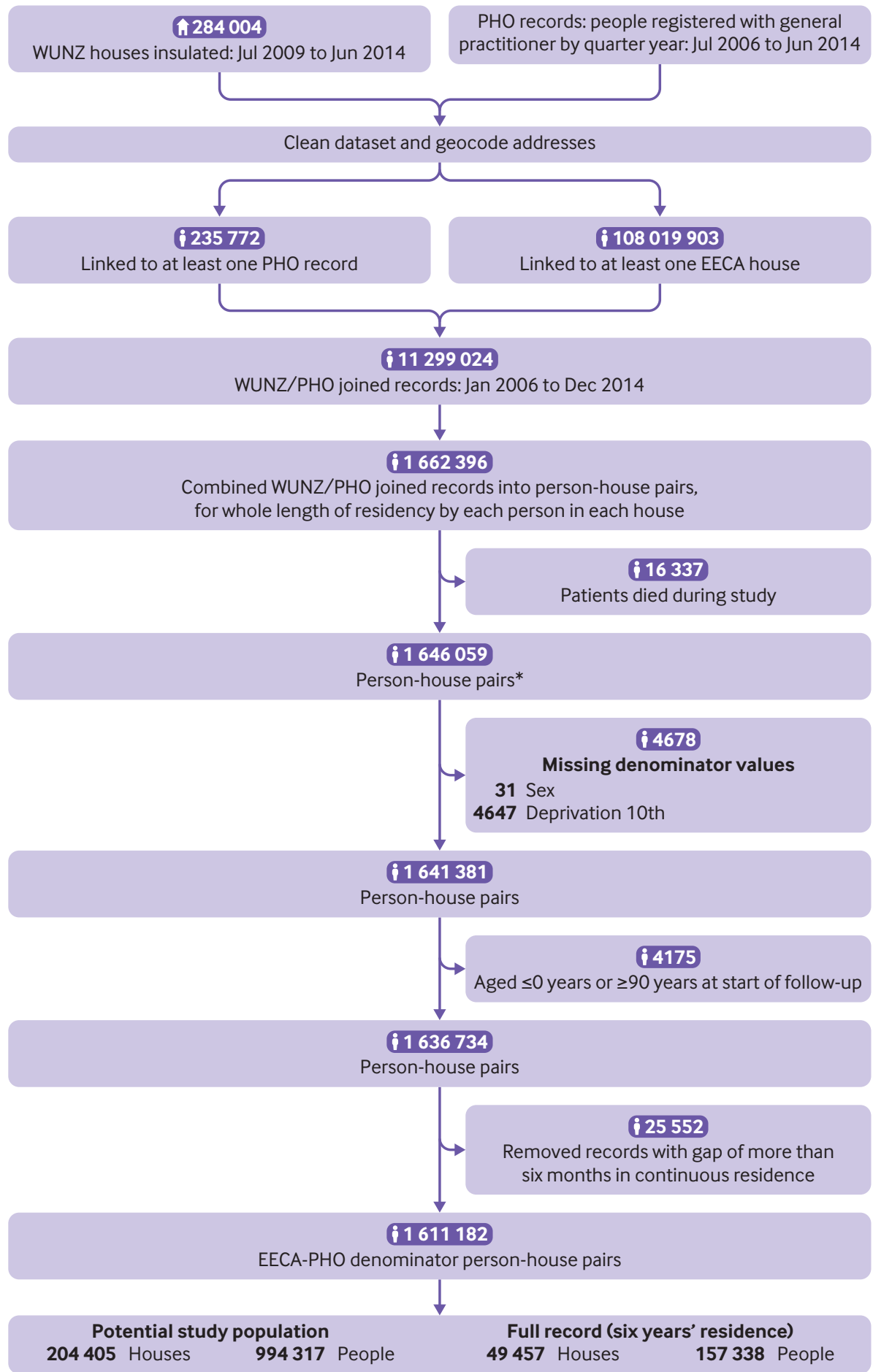

Fig 2 | Address matching process to link WUNZ houses to residents using primary health organisation records. *A person-house pair represents a record for each person in each house, if a person lived in more than one WUNZ house, then a new record is created for each house they inhabited. WUNZ=Warm-up New Zealand: Heat Smart programme; $\mathrm{PHO}=$ primary health organisation; EECA=Energy Efficiency and Conservation Authority

cardiovascular disease (I00-I99) in people aged 15-65 years and in adults older than 65 years, upper respiratory tract infection (J00-J06), lower respiratory tract infection (J09-J16, J18, J20-J22), asthma (J45J46), chronic obstructive pulmonary disease (J40-44, J47) in adults older than 65 years, and ischaemic heart disease (I20-I25) in adults older than 65 years.
Unless otherwise stated, analyses were conducted for all ages-children younger than 15 years, adults aged 15-65 years, and adults older than 65 years. We also conducted a sensitivity analysis, excluding Christchurch City and Waimakariri, to control for potential confounding by the earthquakes that occurred in Christchurch in September 2010 and 


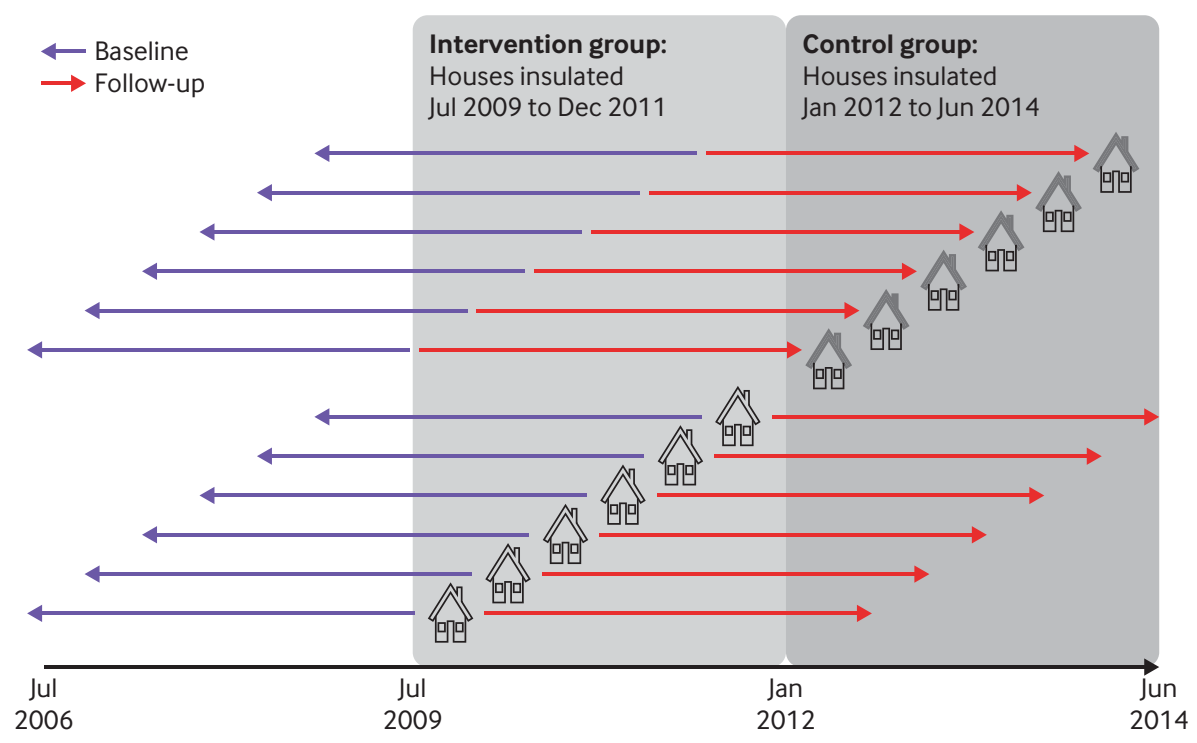

Fig 3 | Method for assignment of intervention and control groups and baseline and follow-up timeframes

February 2011. Finally, as participants who died had higher hospital admission rates, we compared results obtained with and without those who died during the study.

\section{Public and patient involvement}

No patients were involved in setting the research question or the outcome measures, nor were they involved in developing plans for recruitment, design, or implementation of the study. No patients were asked to advise on interpretation or writing up of results. There are no plans to disseminate the results of the research to study participants or the relevant patient community.

\section{Results}

Overall, 1611182 person-house pairs, representing 204405 houses, 994317 people, were included in the study. The nested cohort with six years continual occupancy consisted of $15.9 \%$ of people $(n=157338)$, $24.2 \%$ of houses $(n=49457)$, and $9.8 \%$ of person years $(n=1027881)$.

A total of 699970 hospital admissions were identified in the study population between July 2006 and June 2014, of which 268344 (38.3\%) occurred during baseline or follow-up. After exclusions, 234873 hospital admissions remained for analysis, with $35.3 \%(n=82958)$ of these in the six year continual occupancy nested cohort.

Table 1 lists the personal characteristics of the intervention and control groups. The intervention group had a lower proportion of Māori than the control group (16.9\% $v 20.6 \%$ ) as well as a lower proportion of Pacific Peoples (6.2\% $v$ 8.6\%). The intervention group also had fewer people in small area level, socioeconomic most deprived fifth (20.5\% v 24.0\%) and a greater number in (colder) climate zone 3 $(25.1 \% v 18.3 \%)$. A greater number of houses in the intervention group had heating installed $(18.2 \% \mathrm{v}$
5.0\%) and a lower number had whole house (ceiling and underfloor) insulation (49.2\% $v$ 56.6\%). The six year continual occupancy nested cohort was older than the total population, had particularly low representation among those aged 15 to 45 years, and had a lower proportion of Māori and Pacific Peoples.

\section{Hospital admissions by condition}

Hospital admission rates after the intervention increased in the intervention and control groups for all population categories and conditions, with the exception of Pacific Peoples (rate ratio 0.94, 95\% confidence interval 0.90 to 0.98$)$, asthma (0.92, 0.86 to 0.99$)$, cardiovascular disease $(0.90,0.88$ to 0.93$)$, and ischaemic heart disease for adults older than 65 years (total population: $0.79,0.75$ to 0.84 ; six year continual residency nested cohort: $0.76,0.65$ to 0.90 ). All reductions in hospital admission rates were in the intervention group.

The overall increase in hospital admission rates was significantly reduced in the intervention group compared with control group (relative rate ratio 0.89 , $95 \%$ confidence interval 0.88 to 0.90 ), representing 9.26 (9.05 to 9.47) fewer hospital admissions per 1000 in the intervention population. This effect was more pronounced for respiratory disease $(0.85,0.81$ to 0.90$)$ and cardiovascular disease $(0.86,0.82$ to 0.90) when analysed separately (fig 4). Among specific conditions, reductions in comparative rates of hospital admission were greatest for asthma in all ages $(0.80$, 0.70 to 0.90 ), chronic obstructive pulmonary disease in adults older than 65 years $(0.80,0.70$ to 0.91$)$, and ischaemic heart disease in adults older than 65 years $(0.75,0.66$ to 0.83$)$ (fig 4$)$. Although the effect did not reach statistical significance in the six year continual residency nested cohort for these more specific disease categories, a reduction in comparative rates of hospital admission remained for all conditions except chronic obstructive pulmonary disease. 


\begin{tabular}{|c|c|c|c|c|}
\hline \multirow[b]{2}{*}{ Characteristics } & \multicolumn{2}{|c|}{ Total population } & \multicolumn{2}{|c|}{ Six year continual occupancy nested cohor } \\
\hline & Intervention group & Control group & Intervention group & Control group \\
\hline \multicolumn{5}{|l|}{ People } \\
\hline No of people & 464614 & 529703 & 83482 & 73856 \\
\hline \multicolumn{5}{|l|}{ Ethnicity: } \\
\hline Māori & $78392(16.9)$ & $109083(20.6)$ & $9017(10.8)$ & $8899(12.0)$ \\
\hline Pacific peoples & $28972(6.2)$ & $45363(8.6)$ & $3868(4.6)$ & $4749(6.4)$ \\
\hline European & $301457(64.9)$ & $316670(59.8)$ & $62046(74.3)$ & $53054(71.8)$ \\
\hline Other & $55793(11.1)$ & $58587(11.1)$ & $8551(10.2)$ & $7154(9.7)$ \\
\hline \multicolumn{5}{|l|}{ Sex; } \\
\hline Male & $219453(47.2)$ & $250079(47.2)$ & $36972(44.3)$ & $33462(45.3)$ \\
\hline Female & $245161(52.8)$ & $279624(52.8)$ & $46510(55.7)$ & $40394(54.7)$ \\
\hline \multicolumn{5}{|l|}{ Age at study start (years): } \\
\hline $0-4$ & 63209 (13.6) & $61769(11.7)$ & $5308(6.4)$ & $1423(1.9)$ \\
\hline $9-14$ & $61206(13.2)$ & $76887(14.5)$ & $10201(12.2)$ & $9694(13.1)$ \\
\hline $15-24$ & $64425(13.9)$ & $84675(16.0)$ & $4590(5.5)$ & $6350(8.6)$ \\
\hline $25-34$ & $70780(15.2)$ & $81672(15.4)$ & $5763(6.9)$ & $3771(5.1)$ \\
\hline $35-44$ & $67213(14.5)$ & $73590(13.9)$ & $11339(13.6)$ & $8493(11.5)$ \\
\hline $45-54$ & $49838(10.7)$ & $57679(10.9)$ & $12851(15.4)$ & $12333(16.7)$ \\
\hline $55-64$ & $39057(8.4)$ & $48334(9.1)$ & $14039(16.8)$ & $16829(22.8)$ \\
\hline $65-74$ & $29630(6.4)$ & $23964(4.5)$ & $12820(15.4)$ & $7540(10.2)$ \\
\hline $75-84$ & $15829(3.4)$ & $16731(3.2)$ & $5960(7.1)$ & $6335(8.6)$ \\
\hline$\geq 85$ & $3427(0.7)$ & $4402(0.8)$ & $611(0.7)$ & $1088(1.5)$ \\
\hline \multicolumn{5}{|l|}{ Houses } \\
\hline No of houses & 102755 & 101650 & 26754 & 22703 \\
\hline \multicolumn{5}{|l|}{ Deprivation fifth*: } \\
\hline First (least deprived) & $16098(15.7)$ & $14879(14.6)$ & $4729(17.7)$ & 3976 (17.5) \\
\hline Second & 19470 (18.9) & $17879(17.6)$ & $5274(19.7)$ & $4223(18.6)$ \\
\hline Third & $21850(21.3)$ & $20409(20.1)$ & $5699(21.3)$ & $4658(20.5)$ \\
\hline Fourth & $24229(23.6)$ & $24066(23.7)$ & $6058(22.6)$ & $5208(22.9)$ \\
\hline Fifth (most deprived) & $21108(20.5)$ & $24417(24.0)$ & $4994(18.7)$ & $4638(20.4)$ \\
\hline \multicolumn{5}{|l|}{ Climate zone: } \\
\hline CZ1: Far North, Auckland and Coromandel Peninsula) & $25430(24.7)$ & $28258(27.8)$ & $5639(21.1)$ & $5436(23.9)$ \\
\hline CZ2: rest of North Island (excluding Central Plateau) & $51528(50.1)$ & $54748(53.9)$ & $13307(49.7)$ & $11862(52.2)$ \\
\hline CZ3: South Island and Central Plateau & $25797(25.1)$ & $18644(18.3)$ & $7808(29.2)$ & $5405(23.8)$ \\
\hline \multicolumn{5}{|l|}{ Intervention: } \\
\hline Insulation and heating & $18734(18.2)$ & $5039(5.0)$ & $4502(16.8)$ & $988(4.3)$ \\
\hline Whole house insulation (ceiling and underfloor) & $50523(49.2)$ & $57567(56.6)$ & $13069(48.8)$ & $12548(55.3)$ \\
\hline Ceiling insulation & $19615(19.1)$ & $20211(19.9)$ & $5444(20.3)$ & $4828(21.3)$ \\
\hline Underfloor insulation & $13148(12.8)$ & $16779(16.5)$ & $3486(13.0)$ & $3779(16.6)$ \\
\hline Insulation top-up & $735(0.7)$ & $2054(2.0)$ & $253(1.0)$ & $560(2.5)$ \\
\hline
\end{tabular}

After adjustment for clustering, using the six year continual residency nested cohort, analyses showed a small impact for all hospital admissions combined, with an increase in the relative rate ratio from 0.89 (0.87 to 0.91$)$ to 0.91 (0.87 to 0.94$)$; the impact increased when results were disaggregated. For all subsequent analyses related to the six year continual occupancy nested cohort, the results are presented after adjustment for clustering (table 2). Repeating analyses including participants who had died during the study did not appreciably change the results: the relative rate ratios for analyses on overall hospital admission rates without and with deaths changed from 0.89 (0.87 to 0.91 ) to 0.91 (0.90 to 0.93 ).

\section{Sociodemographic characteristics}

Pacific Peoples experienced a greater comparative reduction in hospital admission rates ( $0.82,0.77$ to 0.88 ) than Māori (0.93, 0.89 to 0.97); however, when the six year continual occupancy nested cohort was examined, the effect size was similar for both: Pacific Peoples (0.86, 0.75 to 0.98$)$ and Māori (0.86, 0.77 to 0.95$)$.
When age groups were analysed separately, differences in relative rates of hospital admissions were small. However, owing to higher hospital admission rates among people aged 65 years or older, the absolute reduction in hospital admissions per 1000 population was far higher for this group (28.62, 27.32 to 30.57 ).

Little difference was found in the relative rate ratio between deprivation fifths. However, owing to increases in hospital admission rates as levels of deprivation increased, the absolute reduction in hospital admissions in the intervention group was higher in the fourth fifth of deprivation 12.61 (11.89 to 13.18) and in the fifth fifth 11.70 (11.03 to 12.23) per 1000 population compared with the first fifth 7.41 (7.07 to 7.83 ) per 1000 population.

\section{Climate zone}

Little difference was found in the relative rate ratios between climate zones. When a sensitivity analysis was conducted to adjust for the impact of the earthquakes in Christchurch in 2010 and 2011, the difference in 
effect of insulation between the total population $(0.87$, 0.85 to 0.90 ) and the six year continual residency nested cohort $(0.96,0.93$ to 0.99$)$ in climate zone 3 was no longer evident; total population (0.91, 0.86 to $0.96)$ and six year continual residency nested cohort $(0.91,0.84$ to 0.97$)$.

\section{Intervention type}

The most effective intervention types were whole house (ceiling and underfloor) insulation (relative rate ratio $0.88,0.85$ to 0.90$)$ and ceiling insulation alone $(0.88$, 0.84 to 0.92 ). Installing heating alongside insulation did not seem to increase the effectiveness of the intervention $(0.89,0.84$ to 0.95$)$ (table 2). When underfloor and topup of existing insulation were installed without other interventions, the effect also failed to reach statistical significance.

\section{Discussion}

This study found a statistically significant reduction in hospital admission rates associated with home insulation when the intervention group was compared with a control group of residents over the same two timeframes who did not receive the intervention. This finding was consistent with previously reported improvements in self-reported health after insulation interventions. ${ }^{7-9}$ The reduction in hospital admission rates was more pronounced for specific respiratory conditions. An earlier intervention study in New Zealand also found improvements in parent reported wheeze (adjusted odds ratio $0.51,0.32$ to 0.81$)$ and dry cough $(0.50$, 0.31 to 0.82 ) among children with asthma, and a non-statistically significant reduction in hospital admissions for respiratory conditions. ${ }^{25}$

\section{Vulnerable populations}

When population vulnerability was considered-for people who had remained in the same house throughout the study (six year continual occupancy nested cohort), Māori and Pacific Peoples particularly benefitted from having insulation retrofitted. This was also true for
Pacific Peoples in the total population. These findings are important as Māori and Pacific Peoples have poorer health outcomes than European and other ethnicities in New Zealand. For example, hospital admission rates in 2013 for all respiratory disease in Māori were twice those for the European and other population (relative risk 2.1), with rates for Pacific Peoples more than two and a half times higher (relative risk 2.6). ${ }^{26}$

Across deprivation fifths, no pattern to relative improvement in health outcomes was observed. It has been suggested that the size and quality of dwellings are more strongly correlated with the thermal efficiency of housing than is neighbourhood deprivation. ${ }^{27}$ An analysis of the pathway between housing improvements and health conditions in Glasgow, Scotland concluded that although energy efficiency measures could help manage symptoms, they did not prevent the occurrence of disease. ${ }^{28}$ In addition, another study cautioned that evaluation of energy efficiency measures provided only a snapshot of historical exposure and that improvements could not mitigate health impacts of cold and damp related exposures built up over a lifetime. ${ }^{8}$ However, as hospital admission rates increased with increasing levels of deprivation leading to greater absolute reductions in hospital admissions in the highest deprivation fifths, targeting more deprived communities could still provide an overall greater impact on health than untargeted interventions. ${ }^{29}$

The effect of home insulation was similar across age groups. The greatest reduction in hospital admissions per 1000 population were, however, shown in people aged 65 years or older, because of higher hospital admission rates in this age group. We also found the most pronounced effect for ischaemic heart disease related hospital admissions in those older than 65 years. Older people ( $\geq 65$ years) have a greater vulnerability to cold housing because of comorbidities and more time spent in the home environment. ${ }^{27} 30$ An analysis of the first year of WUNZ found that older people were over-represented in the study population (compared with the 2006 census), linked to their ability

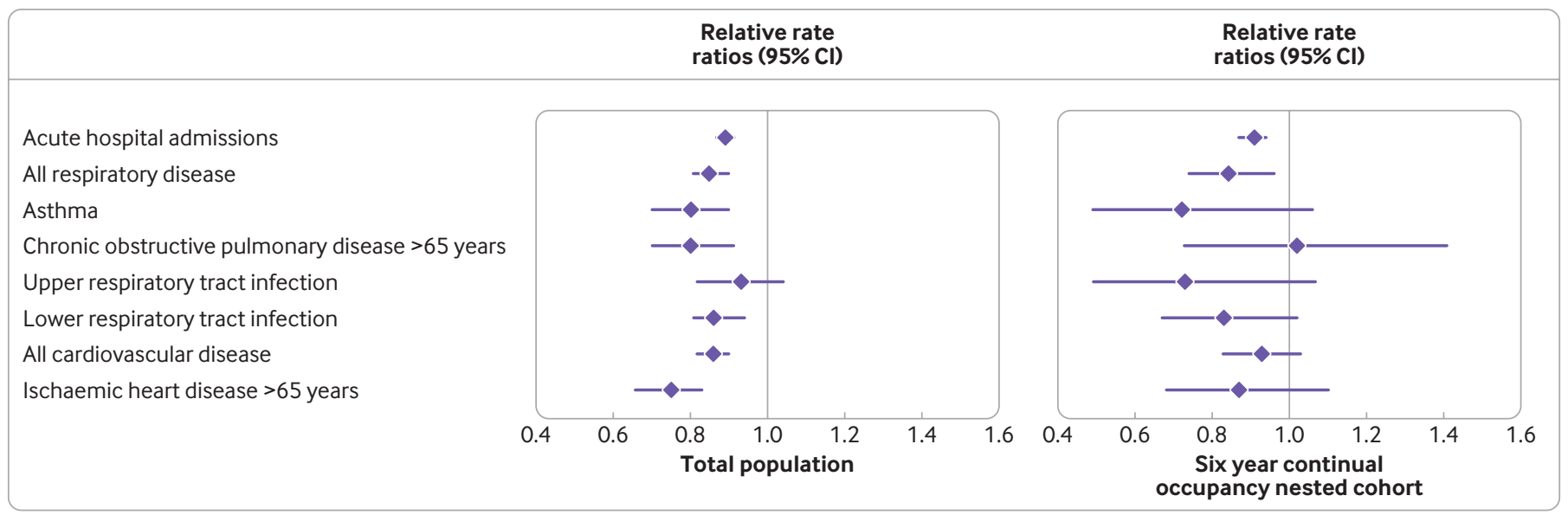

Fig 4 | Difference in difference in rate ratios for disease specific hospital admissions between intervention and control groups before and after insulation was retrofitted 


\begin{tabular}{|c|c|c|c|c|c|c|c|c|}
\hline \multirow[b]{4}{*}{ Subgroups } & \multicolumn{2}{|c|}{ Total population } & \multicolumn{2}{|c|}{$\begin{array}{c}\text { Six year continual occupancy } \\
\text { nested cohortt }\end{array}$} & \multicolumn{2}{|c|}{$\begin{array}{l}\text { Absolute reduction in No of hospital } \\
\text { admissions per } 1000 \text { population } \\
\qquad(95 \% \mathrm{Cl})\end{array}$} & \multicolumn{2}{|c|}{ Relative rate ratio $(95 \% \mathrm{Cl})$} \\
\hline & \multicolumn{2}{|c|}{ No of hospital admissions } & \multicolumn{2}{|c|}{ No of hospital admissions } & \multirow[b]{3}{*}{$\begin{array}{l}\text { Total } \\
\text { Population }\end{array}$} & \multirow{3}{*}{$\begin{array}{l}\text { Six year } \\
\text { continual } \\
\text { occupancy } \\
\text { nested cohort }\end{array}$} & \multirow[b]{3}{*}{$\begin{array}{l}\text { Total } \\
\text { Population }\end{array}$} & \multirow{3}{*}{$\begin{array}{l}\text { Six year } \\
\text { continual } \\
\text { occupancy } \\
\text { nested cohor }\end{array}$} \\
\hline & $\begin{array}{l}\text { Intervention } \\
\text { group }\end{array}$ & Control group & $\begin{array}{l}\text { Intervention } \\
\text { group }\end{array}$ & Control group & & & & \\
\hline & $\begin{array}{l}\text { Baseline/ } \\
\text { follow-up }\end{array}$ & $\begin{array}{l}\text { Baseline/ } \\
\text { follow-up }\end{array}$ & $\begin{array}{l}\text { Baseline/ } \\
\text { follow-up }\end{array}$ & $\begin{array}{l}\text { Baseline/ } \\
\text { follow-up }\end{array}$ & & & & \\
\hline All & $56881 / 63766$ & $50922 / 63304$ & $19478 / 24961$ & $15824 / 22695$ & $\begin{array}{l}9.26 \\
(9.05 \text { to } 9.47)\end{array}$ & $\begin{array}{l}7.55 \\
\text { ( } 7.22 \text { to } 7.80)\end{array}$ & $\begin{array}{l}0.89 \\
(0.87 \text { to } 0.91)\end{array}$ & $\begin{array}{l}0.91 \\
\text { (0.87 to } 0.94)\end{array}$ \\
\hline $\begin{array}{l}\text { All excluding } \\
\text { Christchurch }\end{array}$ & $51091 / 57477$ & $47977 / 59486$ & $17417 / 22324$ & $14681 / 20966$ & $\begin{array}{l}9.28 \\
(9.07 \text { to } 9.49)\end{array}$ & $\begin{array}{l}7.44 \\
(7.19 \text { to } 7.77)\end{array}$ & $\begin{array}{l}0.89 \\
(0.87 \text { to } 0.91)\end{array}$ & $\begin{array}{l}0.91 \\
(0.88 \text { to } 0.95)\end{array}$ \\
\hline \multicolumn{9}{|l|}{ Ethnicity: } \\
\hline Māori & $9879 / 11326$ & $10176 / 12653$ & $2582 / 2978$ & $2087 / 2909$ & $\begin{array}{l}8.00 \\
(7.66 \text { to } 8.34)\end{array}$ & $\begin{array}{l}11.57 \\
(10.36 \text { to } 12.78)\end{array}$ & $\begin{array}{l}0.93 \\
(0.89 \text { to } 0.97)\end{array}$ & $\begin{array}{l}0.86 \\
(0.77 \text { to } 0.95)\end{array}$ \\
\hline Pacific Peoples & $3946 / 3916$ & $4657 / 5752$ & $1217 / 1398$ & $1304 / 1822$ & $\begin{array}{l}18.00 \\
(16.90 \text { to } 19.54)\end{array}$ & $\begin{array}{l}18.22 \\
(15.89 \text { to } 20.76)\end{array}$ & $\begin{array}{l}0.82 \\
(0.77 \text { to } 0.88)\end{array}$ & $\begin{array}{l}0.86 \\
(0.75 \text { to } 0.98)\end{array}$ \\
\hline European & $39666 / 44490$ & $33080 / 40904$ & $14516 / 19263$ & $11492 / 16720$ & $\begin{array}{l}8.70 \\
(9.48 \text { to } 9.92) \\
\end{array}$ & $\begin{array}{l}6.04 \\
(5.78 \text { to } 6.30)\end{array}$ & $\begin{array}{l}0.88 \\
(0.86 \text { to } 0.90)\end{array}$ & $\begin{array}{l}0.92 \\
(0.88 \text { to } 0.96)\end{array}$ \\
\hline Other & $3190 / 4034$ & $3009 / 3995$ & $1163 / 1322$ & $941 / 1244$ & $\begin{array}{l}4.59 \\
(4.29 \text { to } 4.89)\end{array}$ & $\begin{array}{l}6.22 \\
(5.36 \text { to } 7.29) \\
\end{array}$ & $\begin{array}{l}0.91 \\
(0.84 \text { to } 0.97)\end{array}$ & $\begin{array}{l}0.87 \\
(0.75 \text { to } 1.02)\end{array}$ \\
\hline \multicolumn{9}{|l|}{ Sex: } \\
\hline Male & $27409 / 30259$ & $24837 / 30777$ & 9379/11839 & $7738 / 11244$ & $\begin{array}{l}10.31 \\
\text { (9.96 to } 10.54)\end{array}$ & $\begin{array}{l}10.12 \\
(1.09 \text { to } 11.62)\end{array}$ & $\begin{array}{l}0.88 \\
(0.85 \text { to } 0.90)\end{array}$ & $\begin{array}{l}0.88 \\
(0.81 \text { to } 0.93)\end{array}$ \\
\hline Female & $29272 / 33507$ & $26085 / 32527$ & $10099 / 13122$ & $8086 / 11451$ & $\begin{array}{l}8.09 \\
(7.91 \text { to } 8.36) \\
\end{array}$ & $\begin{array}{l}5.50 \\
(5.20 \text { to } 5.80) \\
\end{array}$ & $\begin{array}{l}0.90 \\
(0.89 \text { to } 0.93)\end{array}$ & $\begin{array}{l}0.93 \\
(0.88 \text { to } 0.98)\end{array}$ \\
\hline \multicolumn{9}{|l|}{ Age (years): } \\
\hline $0-14$ & $8747 / 10320$ & $8156 / 9847$ & $1952 / 1230$ & $1342 / 1018$ & $\begin{array}{l}4.28 \\
(4.09 \text { to } 4.47)\end{array}$ & $\begin{array}{l}8.41 \\
(7.94 \text { to } 8.98)\end{array}$ & $\begin{array}{l}0.92 \\
(0.88 \text { to } 0.96)\end{array}$ & $\begin{array}{l}0.89 \\
\text { (0.84 to } 0.95)\end{array}$ \\
\hline $15-64$ & $25576 / 27248$ & $24981 / 29987$ & $8247 / 8563$ & $7695 / 9125$ & $\begin{array}{l}6.75 \\
(6.52 \text { to } 6.90)\end{array}$ & $\begin{array}{l}5.91 \\
\text { (5.38 to } 6.31 \text { ) }\end{array}$ & $\begin{array}{l}0.89 \\
(0.86 \text { to } 0.91)\end{array}$ & $\begin{array}{l}0.89 \\
\text { (0.81 to } 0.95)\end{array}$ \\
\hline $265 \ddagger$ & $22358 / 26198$ & $17785 / 23470$ & 9279/15168 & $6787 / 12552$ & $\begin{array}{l}28.62 \\
\text { (27.32 to } 30.57)\end{array}$ & $\begin{array}{l}18.66 \\
\text { (17.63 to } 19.69)\end{array}$ & $\begin{array}{l}0.88 \\
(0.86 \text { to } 0.14)\end{array}$ & $\begin{array}{l}0.91 \\
(0.86 \text { to } 0.96)\end{array}$ \\
\hline \multicolumn{9}{|l|}{ Deprivation fifth§: } \\
\hline $\begin{array}{l}\text { First } \\
\text { (least deprived) }\end{array}$ & $6383 / 7271$ & $5024 / 6299$ & $2577 / 3201$ & $1886 / 2648$ & $\begin{array}{l}7.41 \\
\text { (7.07 to } 7.83)\end{array}$ & $\begin{array}{l}6.50 \\
(5.84 \text { to } 7.23)\end{array}$ & $\begin{array}{l}0.88 \\
(0.84 \text { to } 0.93)\end{array}$ & $\begin{array}{l}0.89 \\
\text { (0.80 to } 0.99)\end{array}$ \\
\hline Second & $8258 / 9442$ & $7018 / 8727$ & $3032 / 4004$ & $2481 / 3378$ & $\begin{array}{l}8.13 \\
(7.59 \text { to } 8.58)\end{array}$ & $\begin{array}{l}2.51 \\
(2.28 \text { to } 2.74) \\
\end{array}$ & $\begin{array}{l}0.90 \\
(0.84 \text { to } 0.95)\end{array}$ & $\begin{array}{l}0.98 \\
\text { (0.89 to } 1.07)\end{array}$ \\
\hline Third & $10758 / 12367$ & $8946 / 11408$ & $3807 / 4951$ & $2897 / 4360$ & $\begin{array}{l}8.88 \\
\text { (8.38 to } 9.38) \\
\end{array}$ & $\begin{array}{l}10.14 \\
\text { (9.32 to } 11.07)\end{array}$ & $\begin{array}{l}0.89 \\
(0.84 \text { to } 0.94)\end{array}$ & $\begin{array}{l}0.87 \\
(0.80 \text { to } 0.95)\end{array}$ \\
\hline Fourth & $14614 / 16426$ & $13051 / 16466$ & $4739 / 6069$ & $3864 / 5713$ & $\begin{array}{l}12.61 \\
\text { (11.89 to } 13.18)\end{array}$ & $\begin{array}{l}11.21 \\
\text { (10.57 to } 12.24)\end{array}$ & $\begin{array}{l}0.88 \\
(0.83 \text { to } 0.92)\end{array}$ & $\begin{array}{l}0.87 \\
(0.82 \text { to } 0.95)\end{array}$ \\
\hline $\begin{array}{l}\text { Fifth } \\
\text { (most deprived) }\end{array}$ & $16668 / 18260$ & $16883 / 20404$ & $5323 / 6736$ & $4696 / 6596$ & $\begin{array}{l}11.70 \\
\text { (11.03 to } 12.23)\end{array}$ & $\begin{array}{l}7.23 \\
(6.67 \text { to } 7.71) \\
\end{array}$ & $\begin{array}{l}0.90 \\
(0.86 \text { to } 0.94)\end{array}$ & $\begin{array}{l}0.92 \\
(0.86 \text { to } 0.99)\end{array}$ \\
\hline \multicolumn{9}{|l|}{ Climate zone: } \\
\hline $\begin{array}{l}\text { CZ1: Far North, } \\
\text { Auckland and } \\
\text { Coromandel Peninsula) }\end{array}$ & $16592 / 17839$ & $16778 / 19349$ & $5618 / 6716$ & $4926 / 6732$ & $\begin{array}{l}8.81 \\
(8.31 \text { to } 9.21)\end{array}$ & $\begin{array}{l}8.17 \\
\text { (7.61 to } 8.73 \text { ) }\end{array}$ & $\begin{array}{l}0.91 \\
(0.88 \text { to } 0.94)\end{array}$ & $\begin{array}{l}0.88 \\
(0.82 \text { to } 0.94)\end{array}$ \\
\hline $\begin{array}{l}\text { CZ2: rest of North } \\
\text { Island (excluding } \\
\text { Central Plateau) }\end{array}$ & $12280 / 14342$ & $8373 / 10887$ & $4547 / 6188$ & $3075 / 4768$ & $\begin{array}{l}8.78 \\
\text { (8.48 to } 9.17)\end{array}$ & $\begin{array}{l}8.81 \\
\text { (8.32 to } 9.30)\end{array}$ & $\begin{array}{l}0.89 \\
\text { (0.85 to } 0.93)\end{array}$ & $\begin{array}{l}0.89 \\
(0.84 \text { to } 0.94)\end{array}$ \\
\hline $\begin{array}{l}\text { CZ3: South Island and } \\
\text { Central Plateau }\end{array}$ & $27809 / 31585$ & $25771 / 33068$ & $9313 / 12057$ & $7823 / 11195$ & $\begin{array}{l}9.70 \\
(9.47 \text { to } 10.15)\end{array}$ & $\begin{array}{l}6.32 \\
(6.12 \text { to } 6.39) \\
\end{array}$ & $\begin{array}{l}0.87 \\
(0.85 \text { to } 0.90)\end{array}$ & $\begin{array}{l}0.96 \\
(0.93 \text { to } 0.99)\end{array}$ \\
\hline $\begin{array}{l}\text { CZ3 excluding } \\
\text { Christchurch }\end{array}$ & $6690 / 8053$ & $5428 / 7069$ & $2486 / 3551$ & $3551 / 1932$ & $\begin{array}{l}7.08 \\
(6.53 \text { to } 7.70) \\
\end{array}$ & $\begin{array}{l}9.72 \\
\text { (8.98 to } 10.36)\end{array}$ & $\begin{array}{l}0.91 \\
(0.86 \text { to } 0.96)\end{array}$ & $\begin{array}{l}0.91 \\
\text { (0.84 to } 0.97)\end{array}$ \\
\hline \multicolumn{9}{|l|}{ Intervention: } \\
\hline Insulation and heating & $10312 / 11744$ & $2552 / 3088$ & $3463 / 4543$ & $770 / 1031$ & $\begin{array}{l}8.60 \\
(8.12 \text { to } 9.18)\end{array}$ & $\begin{array}{l}1.26 \\
(1.09 \text { to } 1.44) \\
\end{array}$ & $\begin{array}{l}0.89 \\
(0.84 \text { to } 0.95)\end{array}$ & $\begin{array}{l}0.98 \\
(0.85 \text { to } 1.12)\end{array}$ \\
\hline $\begin{array}{l}\text { Whole house (ceiling } \\
\text { and underfloor) }\end{array}$ & $29391 / 32906$ & $30166 / 38121$ & $9990 / 12590$ & $8988 / 13089$ & $\begin{array}{l}11.09 \\
\text { (10.83 to } 11.47)\end{array}$ & $\begin{array}{l}9.62 \\
(9.18 \text { to } 10.06)\end{array}$ & $\begin{array}{l}0.88 \\
(0.85 \text { to } 0.90)\end{array}$ & $\begin{array}{l}0.87 \\
(0.83 \text { to } 0.92)\end{array}$ \\
\hline Ceiling insulation & $10111 / 11322$ & $9562 / 11981$ & $3548 / 4720$ & $3185 / 4792$ & $\begin{array}{l}10.42 \\
\text { (9.95 to } 10.89 \text { ) }\end{array}$ & $\begin{array}{l}10.84 \\
\text { (10.11 to } 11.57)\end{array}$ & $\begin{array}{l}0.88 \\
(0.84 \text { to } 0.92)\end{array}$ & $\begin{array}{l}0.89 \\
(0.83 \text { to } 0.95)\end{array}$ \\
\hline $\begin{array}{l}\text { Underfloor } \\
\text { insulation }\end{array}$ & $6432 / 7249$ & $7582 / 8866$ & $2298 / 2854$ & $2508 / 3243$ & $\begin{array}{l}4.75 \\
(4.50 \text { to } 5.00)\end{array}$ & $\begin{array}{l}-0.61 \\
(-0.55 \text { to }-0.67)\end{array}$ & $\begin{array}{l}0.94 \\
(0.90 \text { to } 0.99)\end{array}$ & $\begin{array}{l}1.00 \\
(0.90 \text { to } 1.10)\end{array}$ \\
\hline Insulation top-up & $435 / 545$ & $1060 / 1248$ & $179 / 254$ & $373 / 540$ & $\begin{array}{l}-2.03 \\
(-1.73 \text { to }-2.33)\end{array}$ & $\begin{array}{l}1.15 \\
\text { (0.82 to } 1.62)\end{array}$ & $\begin{array}{l}1.02 \\
(0.87 \text { to } 1.17)\end{array}$ & $\begin{array}{l}0.97 \\
\text { (0.69 to } 1.37 \text { ) }\end{array}$ \\
\hline
\end{tabular}

*All non-elective admissions excluding maternity and injury related hospital admissions.

†Nested cohort included all residents with six years continual occupancy of their WUNZ (Warm-up New Zealand: Heat Smart) insulated house.

FAlmost all hospital admissions in the $\geq 65$ age group.

§New Zealand deprivation index 2013. 
to access capital under the WUNZ subsidy model, and targeting by service providers. ${ }^{31}$

\section{Intervention type}

Some variation was found in effect on hospital admission rates by type of insulation installed. Whole house (ceiling and underfloor) insulation, ceiling insulation, and installation of a heater alongside insulation, had similar statistically significant results for acute hospital admissions in the total population. This finding was consistent with a study in England, which recorded the lowest indoor temperatures among houses without ceiling insulation, ${ }^{27}$ and a study in Glasgow, Scotland, which identified increased odds of recovery from a circulatory condition when central heating was part of a housing improvement programme. ${ }^{28}$ The lack of increased effectiveness identified when a heater was included in the intervention reflected findings of an earlier WUNZ study ${ }^{13}$; however, current results should be treated with caution given the early phasing out of the heater subsidy. The primary aim of the WUNZ heater subsidy was to provide a clean heating source to replace open fires and inefficient log burners. It was targeted towards reducing outdoor air pollution and was acknowledged at the time as having the potential to provide less warmth than some of the solid fuel burners being replaced. ${ }^{32}$ In addition, the intervention would only have been effective if households used the new heaters. Several studies found that New Zealanders' use of home heating was relatively low and often restricted to the main living area. ${ }^{1033}$ This was particularly true of low income households, who paid the highest proportion of their income on electricity and were more likely to use prepayment metres, something that allowed them to use self-disconnection as a method of managing their energy budgets. ${ }^{34}$

\section{Limitations of this study}

Our study has several limitations. Linking existing datasets involved a quasi-experimental study method that can increase risk of bias due to non-randomisation and an inability to match intervention and control houses. ${ }^{33}$ This risk was managed by using the difference-in-difference model and sourcing the intervention and control populations from the same programme. $^{3536}$

As a result of inaccuracies in address data resulting in records being assigned to an incorrect Land Information New Zealand address string, the study was at risk of both type I and type II errors. In addition, patients who did not update their general practitioner within three months of a change of address and residents who were not registered with a general practice would not have been identified through the data linkage process described and would therefore not have been included in the study. Some evidence suggested that those on a low income who rent and recent migrant populations were more likely to not be registered with a general practice, owing to higher levels of mobility and lower levels of contact with health services. ${ }^{21}$ This could have reduced the strength of the relation between improvements in home insulation and health outcomes across deprivation fifths.

The ending of the heater subsidy in December 2012 limited interpretation of results for the subgroup of households that received heaters alongside insulation. Because of the way the cohort was split between intervention and control groups, using a mid-point of December 2011, most of those who received a heater subsidy were in the intervention group, further complicating comparisons between the two groups.

Although there was no selection or prioritisation process for obtaining a subsidy, the motivation of householders to apply for one might cause unobserved differences between the intervention and control groups. Were the information available and the potential study population large enough, matching by key indicators would have further added to the internal validity of the study. ${ }^{36}$ We used the six year continual occupancy nested cohort as a comparator, to control for differences between baseline and follow-up and also to determine whether clustering by household influenced the results. These indicated small differences in the relative rate ratio for larger groups but did show greater differences when the datasets were disaggregated, resulting in fewer statistically significant findings for specific disease categories.

\section{Conclusion}

The study showed that the retrofitting of home insulation was associated with a reduction in frequency of hospital admissions. The size of the reduction was more pronounced for respiratory disease. Future studies should examine in more detail the differences in the effectiveness of insulation among different subgroups within the population, to better target interventions to those who would benefit most from them.

The impact of the intervention on cold associated hospital admissions varied with the type of insulation retrofitted, and no additional benefit was indicated from combining insulation and a heater. This might have been due to the low numbers in this group, particularly among the control population. However, concerns about the energy costs of running heaters and low expectations of warmth among residents might have led to under-utilisation of the heaters provided. Further study should focus on whether improvements in energy efficiency result in long term behavioural changes, and on the impact these changes can have on cold associated ill health.

We thank the following people and organisations for their support: David Briggs (Imperial College London) for advice on study design; Stephen Haslett (Massey University) for overview and advice on statistical analysis; James Stanley (University of Otago Wellington) and Marine Corbin and Mathu Shanthakumar (Massey University) for statistical advice and support with SAS software; and the Energy Efficiency and Conservation Authority and New Zealand Ministry of Health for technical advice and provision of the datasets.

Contributors: CF conducted the study under the guidance of LTB, PHC, and JD. All authors read, edited, and approved the final manuscript. The corresponding author attests that all listed authors meet authorship criteria and that no others meeting the criteria have been omitted. 
Funding: No external funding was sought, or provided, for this study. Competing interests: All authors have completed the ICMJE uniform disclosure form at www.icmje.org/coi_disclosure.pdf and declare: no support from any organisation for the submitted; no financial relationships with any organisations that might have an interest in the submitted work in the previous three years; no other relationships or activities that could appear to have influenced the submitted work.

Ethical approval: The study was approved by the New Zealand Ministry of Health, Health and Disability Ethics Committee (15CEN8AM01).

Data sharing: No additional data available.

The lead author (CF) affirms that the manuscript is an honest, accurate, and transparent account of the study being reported; that no important aspects of the study have been omitted; any discrepancies from the study as planned (and, if relevant, registered) have been explained.

Dissemination to participants and related patient and public communities: It is not possible to disseminate results of the study to individuals as all records have been anonymised as part of the data linkage process. Results can be disseminated to the organisations that provided the original datasets, on request.

Provenance and peer review: Not commissioned; externally peer reviewed.

Publisher's note: Published maps are provided without any warranty of any kind, either express or implied. BMJ remains neutral with regard to jurisdictional claims in published maps.

This is an Open Access article distributed in accordance with the Creative Commons Attribution Non Commercial (CC BY-NC 4.0) license, which permits others to distribute, remix, adapt, build upon this work non-commercially, and license their derivative works on different terms, provided the original work is properly cited and the use is non commercial. See: http://creativecommons.org/licenses/by-nc/4.0/

1 Hales S, Blakely T, Foster RH, Baker MG, Howden-Chapman P. Seasonal patterns of mortality in relation to social factors. J Epidemiol Community Health 2012;66:379-84. doi:10.1136/ jech.2010.111864

2 Healy JD. Excess winter mortality in Europe: a cross country analysis identifying key risk factors. I Epidemiol Community Health 2003.57.784-9. doi:10.1136/jech.57.10.784

3 Davie GS, Baker MG, Hales S, Carlin JB. Trends and determinants of excess winter mortality in New Zealand: 1980 to 2000 . BMC Public Health 2007:7:263. doi:10.1186/1471-2458-7-263

4 Hunt DRG, Gidman MI. A national field survey of house temperatures. Build Environ 1982;17:175-7.

5 Fisk WJ, Lei-Gomez Q, Mendell MJ. Meta-analyses of the associations of respiratory health effects with dampness and mold in homes. Indoor Air 2007;17:284-96. doi:10.1111/j.16000668.2007.00475.x

6 Shorter C, Crane J, Pierse N, et al, Wellington Region General Practitioner Research Network. Indoor visible mold and mold odor are associated with new-onset childhood wheeze in a dosedependent manner. Indoor Air 2018:28:6-15. doi:10.1111/ ina. 12413

7 Howden-Chapman P, Matheson A, Crane J, et al. Effect of insulating existing houses on health inequality: cluster randomised study in the community. BMJ 2007:334:460-9. doi:10.1136/ bmj.39070.573032.80

8 Heyman B, Harrington BE, Merleau-Pointy N, Stokton H, Ritchie $\mathrm{N}$, Allan TF. Keeping warm and staying well. Does home energy efficiency mediate the relationship between socio-economic status and risk of poorer health? Housing Stud 2005:649-64. doi:10.1080/02673030500114656

9 Grey CNB, Schmieder-Gaite T, liang S, Nascimento C Poortinga W. Cold homes, fuel poverty and energy efficiency improvements: A longitudinal focus group approach. Indoor Built Environ 2017:26:902-13. doi:10.1177/1420326X17703450

10 World Health Organization. Housing and health guidelines. World Health Organization, 2018.

11 National Institute for Health and Care Excellence (NICE). Excess Winter Deaths and IIlness and Health Risks Associated with Cold Homes. NICE Guideline [NG6] 2015. https://www.nice.org.uk/ guidance/ng6 [Accessed 5 August 2019]

12 Preval N, Keall M, Telfar-Barnard L, Grimes A, Howden-Chapman P. Impact of improved insulation and heating on mortality risk of older cohort members with prior cardiovascular or respiratory hospitalisations. BMI Open 2017.7:e018079 doi:10.1136 bmjopen-2017-018079
13 Telfar Barnard L, Preval N, Howden-Chapman P. The impact of retrofitting insulation and new heaters on health service utilisation and costs, pharmaceutical costs and mortality. Evaluation of Warm-up New Zealand: Heat Smart. He Kainga Oranga/Housing and Health Research Programme, Wellington School of Medicine, University of Otago: 2011.

14 World Health Organization. Health impact of low indoor temperatures. World Health Organization Regional Office for Europe, 1987.

15 Pollard A. Could damp homes be too cold/ under heated? BRANZ Study report No: SR389, 2018.

16 Amitrano, L, Kirk, N, Page, I. Market Segmentation of New Zealand Housing Stock. Beacon Pathway. Report No PR106, 2006

17 Page I, Fung J. Housing typologies-Current Stock Prevalence. Beacon Pathways. Report No EN6570/8, 2008.

18 Preval N, Ombler J, Grimes A, Keall M, Howden-Chapman P.Government failure and success: A trans-Tasman comparison of two insulation subsidy schemes. Agenda: A Journal of Policy Analysis and Reform 2019:26;51-65.

19 Grimes A, Denne T, Howden-Chapman P, et al. Cost benefit analysis of the Warm-up New Zealand: Heat Smart Programme. Motu, 2012

20 Atkinson J, Salmond C, Crampton P. NZDep2013 Index of Deprivation. Department of Public Health, Wellington School of Medicine, University of Otago, 2014

21 Telfar Barnard LF, Baker MG, Hales S, Howden-Chapman P. Novel use of three administrative datasets to establish a cohort for environmental health research. BMC Public Health 2015;15:246. doi:10.1186/s12889-015-1580-1

22 Jackson G, Thornley S, Woolston J, Papa D, Bernacchi A, Moore T. Reduced acute hospitalisation with the healthy housing programme. J Epidemiol Community Health 2011;65:588-93. doi:10.1136/ jech.2009.107441

23 Baker M, McDonald A, Zhang J, Howden-Chapman P. Infectious diseases attributed to household crowding in New Zealand: A systematic review and burden of disease estimate. He Kainga Oranga, University of Otago, Wellington. 2013.

24 Anderson P, Craig E, Jackson G, Jackson C. Developing a tool to monitor potentially avoidable hospitalisations in New Zealand children. N Z Med J 2012;125:25-37.

25 Howden-Chapman P, Crane J, Chapman R, Fougere G. Improving health and energy efficiency through community-based housing interventions. Int J Public Health 2011;56:583-8. doi:10.1007 s00038-011-0287-z

26 Telfar Barnard L, Baker M, Pierse N, Zhang J. The impact of respiratory disease in New Zealand: 2014 update. The Asthma Foundation, 2015.

27 Hamilton IG, O'Sullivan A, Huebner G, et al. Old and cold? Findings on the determinants of indoor temperatures in English dwellings during cold conditions. Energy and Buildings, 2017: 142-57.

28 Curl A, Kearns A. Can housing improvements cure or prevent the onset of health conditions over time in deprived areas?BMC Public Health 2015;15:1191-205. doi:10.1186/s12889-015-2524-5

29 Maidment CD, Jones CR, Webb TL, Hathway EA, Gilbertson IM. The impact of household energy efficiency measures on health: A meta-analysis. Energy Policy 2014;65:583-93. doi:10.1016/i. enpol.2013.10.054

30 Webb E, Blane D, de Vries R. Housing and respiratory health at older ages. J Epidemiol Community Health 2013;67:280-5. doi:10.1136/ jech-2012-201458

31 Preval N. Evaluation of Public Health Interventions (unpublished doctoral dissertation). He Kainga Oranga/Housing and Health Research Programme, Wellington School of Medicine, University of Otago, 2015

32 Taylor Baines and Associates. Warm Homes Technical Report: Social Drivers. Ministry for the Environment. Report No 2, 2005

33 Isaacs N, Camilleri M, Burrough L, Pollard A, Saville-Smith K, Rossouw P, Jowett J. Energy use in New Zealand Houses: Final report on the Household Energy End-use Project (HEEP). BRANZ. Report No 221 2010.

34 Howden-Chapman P, Viggers H, Chapman R, O'Dea D, Free S, O'Sullivan K. Warm homes: Drivers of the demand for heating in the residential sector in New Zealand. Energy Policy 2009;37:3387-99. doi:10.1016/j.enpol.2008.12.023

35 Handley MA, Lyles CR, McCulloch C, Cattamanchi A. Selecting and improving quasi-experimental designs in effectiveness and implementation research. Annu Rev Public Health 2018;39:5-25. doi:10.1146/annurev-publhealth-040617-014128

36 White H, Sabarwal S. Quasi-experimental design and methods, Methodological briefs: Impact and Evaluation. UNICEF Office of Research. Report No 8, 2014

Supplementary information: table showing unadjusted hospital admission rates per 1000 person years for different cohorts within the WUNZ population 